\title{
IDENTIFIKASI LARVA IKAN PADA DAERAH MANGROVE DI KABUPATEN WAJO, SULAWESI SELATAN
}

\author{
Agus Kurniawan B ${ }^{a}$,*, Asriani Asriani ${ }^{b}$, Ady Jufric \\ ${ }^{a, b}$ Manajemen Sumber Daya Perairan, Universitas Puangrimaggalatung, Sengkang \\ 'Program Studi Perikanan Tangkap, Universitas Sulawesi Barat \\ *Corresponding author, e-mail: aguskurniawan@uniprima.ac.id
}

\begin{abstract}
Abstrak
Larva ikan merupakan salah satu faktor utama dalam menentukan kelestarian sumberdaya hayati perikanan tawar dan perikanan laut. Stadia larva merupakan stadia yang penting bagi perkembangan, khususnya ikan. Penelitian ini bertujuan untuk mengetahui jenis famili larva ikan, distribusi, kelimpahan, keseragaman, keanekaragaman dan dominansi larva ikan di ekosistem mangrove. Penelitian ini terdiri atas 3 perlakuan dengan masing-masing 3 ulangan. Ketiga jenis perlakuan tersebut adalah perbedaan umur mangrove yaitu: A. Stasiun I (umur mangrove $>10$ tahun), B. Stasiun II (umur mangrove 7 tahun), dan C. Stasiun III (umur mangrove 3 tahun). Hasil penelitian menunjukkan bahwa larva ikan yang tertangkap selama penelitian sebanyak 1.288 individu yang terdiri dari terdiri dari 7 famil yaitu Adrianichthyidae, Carangidae, Clupeidae, Engraulidae, Gerreidae, Gobiidae, dan Megalopidae. Larva ikan yang tertangkap memiliki sebaran yang berbeda-beda pada lokasi penelitian. Famili Gerreidae dan Gobiidae memiliki sebaran yang cukup luas, dimana dapat ditemukan di seluruh wilayah. Hasil analisis Indeks Keanekaragaman (H'), Indeks Keseragaman (e), dan Indeks Dominansi (D) larva ikan menunjukkan nilai yang berfluktuatif. Pada setiap wilayah nilai indeks keanekaragaman dari hasil analisis setiap wilayah menunjukkan keanekaragaman populasi yang rendah.
\end{abstract}

Kata Kunci: Larva, Distribusi, Kelimpahan, Komparasi, Mangrove

\begin{abstract}
Fish larvae are one of the main factors in determining the sustainability of the biological resources of freshwater fisheries and marine fisheries. The larval stage is an important stage for development, especially fish. This study aims to determine the type of fish larvae family, distribution, abundance, uniformity, diversity and dominance of fish larvae in the mangrove ecosystem. This study consisted of 3 treatments with 3 replications each. The three types of treatment are differences in mangrove age, namely: A. Station I (mangrove age $>10$ years), B. Station II (mangrove age 7 years), and C. Station III (mangrove age 3 years). The results showed that 1,288 fish larvae were caught during the study consisting of 7 families, namely Adrianichthyidae, Carangidae, Clupeidae, Engraulidae, Gerreidae, Gobiidae, and Megalopidae. The fish larvae caught have different distribution in the research location. The Gerreidae and Gobiidae families have a fairly wide distribution, which can be found throughout the region. The results of the analysis of Diversity Index (H'), Uniformity Index (e), and Dominance Index (D) of fish larvae show fluctuating values. In each region, the diversity index value from the results of the analysis for each region shows a low population diversity.
\end{abstract}

Keywords : Larvae, Distribution, Abundance, Comparison, Mangrove.

\section{PENDAHULUAN}

Ekosistem Mangrove di bagian barat Kecamatan Sajoanging merupakan salah satu ekosistem mangrove yang masih bertahan secara alami di Kabupaten Wajo. Keberadaannya berperan sangat penting bagi keseimbangan lingkungan maupun masyarakat Sajoanging yang sebagian besar adalah nelayan. Potensi ekosistem mangrove 
di kawasan ini sebagai habitat, feeding ground, nursery juga spawning ground bagi berbagai organisme perairan, yang nantinya akan menunjang keberhasilan awal siklus hidup ikan yang merupakan salah satu faktor penentu tingginya produktivitas perikanan laut [1].

Larva ikan merupakan salah satu faktor utama dalam menentukan kelestarian sumberdaya hayati perikanan tawar dan perikanan laut. Stadia larva merupakan stadia yang penting bagi perkembangan, khususnya ikan. Distribusi dan kelimpahan larva ikan di mangrove merupakan proses rekruitmen alami. Larva ikan bergantung pada fungsi ekologis mangrove untuk melangsungkan kehidupan karena ekosistem mangrove merupakan produsen primer yang mampu menghasilkan sejumlah besar detritus dari serasah daun dan dahan pohon mangrove dimana tersedia banyak makanan bagi berbagai biota yang mencari makan pada ekosistem mangrove tersebut [2].

Sumberdaya larva ikan merupakan generasi penerus dalam rekruitmen stok ikan di perairan. Informasi ini sangatlah penting untuk mengetahui distribusi larva ikan. Tujuan penelitian ini adalah untuk mengetahui jenis famili larva ikan, distribusi, kelimpahan, keseragaman, keanekaragaman dan dominasi larva ikan di ekosistem mangrove Kecamatan Sajoanging. Mengingat pentingnya informasi tentang keberadaan larva ikan sebagai dasar dalam usaha pengelolaan sumberdaya perikanan di Kabupaten Wajo, serta belum tersedianya informasi atau data mengenai distribusi larva ikan di ekosistem mangrove Kecamatan Sajoanging menjadikan penelitian ini perlu dilakukan.

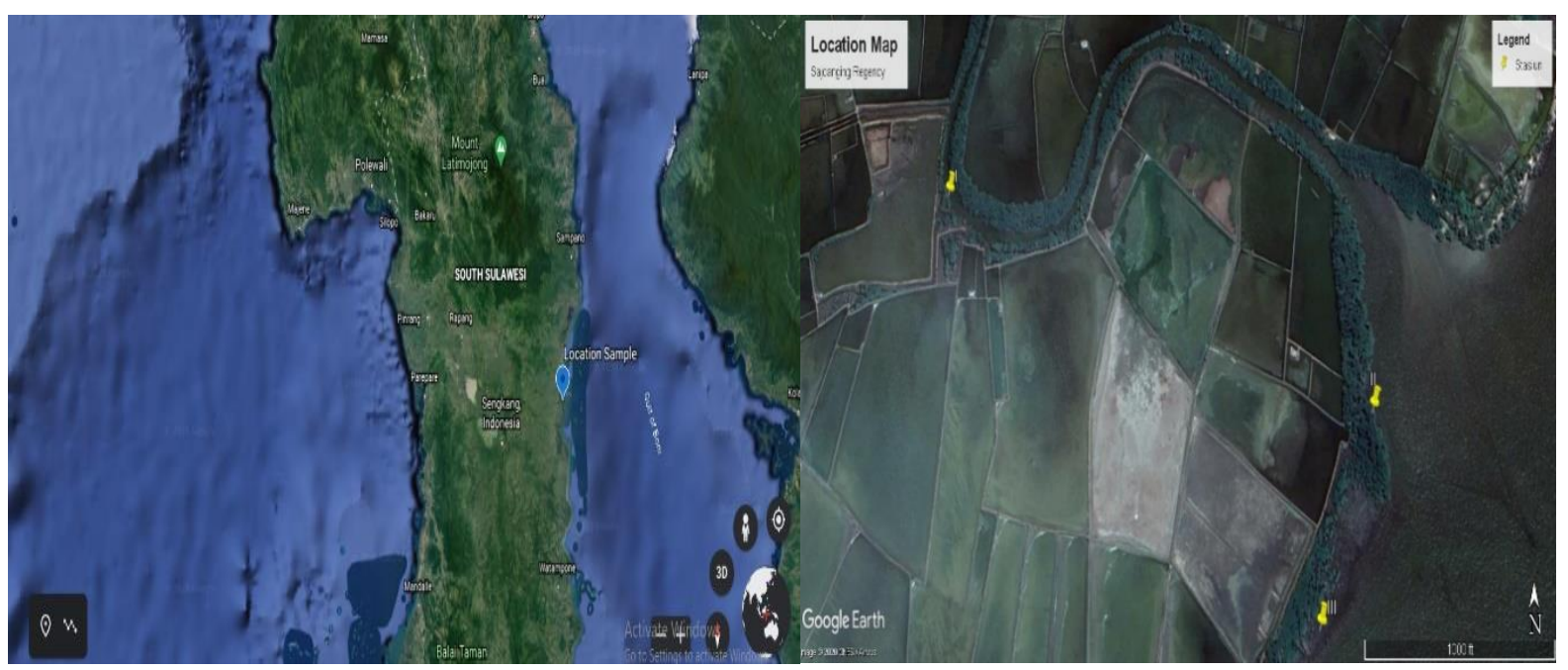

Gambar 1. Peta Lokasi Penelitian

Tabel 1. Stasiun Lokasi Penelitian

\begin{tabular}{|c|c|c|c|c|}
\hline $\begin{array}{c}\text { Lokasi } \\
\text { Penelitian }\end{array}$ & Stasiun & \multicolumn{2}{|c|}{ Posisi Geografis } & Karakteristik Lokasi \\
\hline \multirow{3}{*}{$\begin{array}{l}\text { Kecamatan } \\
\text { Sajoanging }\end{array}$} & I & $4^{0} 1^{\prime} 33^{\prime \prime} \mathrm{LS}$ & $120^{\circ} 18^{\prime} 30^{\prime \prime B T}$ & $\begin{array}{l}\text { Vegetasi Sedang } \\
\text { Warna air cokelat }\end{array}$ \\
\hline & II & $4^{0} 1^{\prime} 40^{\prime \prime} \mathrm{LS}$ & $120^{0} 15^{\prime} 31^{\prime \prime} \mathrm{BT}$ & $\begin{array}{l}\text { Vegetasi Rapat } \\
\text { Warna air keruh cokelat } \\
\text { Dasar Perairan: Lumpur }\end{array}$ \\
\hline & III & $4^{0} 1$ ' $47^{\prime \prime} \mathrm{LS}$ & $120^{0} 18^{\prime} 45^{\prime \prime} \mathrm{BT}$ & $\begin{array}{c}\text { Vegetasi Keanekaragaman } \\
\text { Dasar Perairan: Lumpur }\end{array}$ \\
\hline
\end{tabular}




\section{METODE}

Penelitian ini dilaksanakan pada bulan Maret 2020 dikawasan ekosistem mangrove Desa Bila-bila, Kecamatan Sajoanging, Kabupaten Wajo, Sulawesi selatan. Penelitian terdiri atas 3 perlakuan dengan masing-masing 3 ulangan. Ketiga jenis perlakuan tersebut adalah perbedaan umur mangrove yaitu: A. Stasiun I (umur mangrove $>10$ tahun), B. Stasiun II (umur mangrove 7 tahun), dan C. Stasiun III (umur mangrove 3 tahun). Pengambilan sampel dilakukan setiap minggu selama 3 minggu berturut-turut pada masing-masing wilayah. Setiap minggu dilakukan sampling 1 kali pada setiap wilayah. Sampling larva ikan menggunakan scoop net dengan mesh size $0,5 \mathrm{~mm}$ dan panjang dorongan sejauh 50 meter pada masing-masing wilayah. Sampel larva dimasukkan ke dalam botol sampel volume $250 \mathrm{ml}$ yang sudah disediakan sebelumnya, kemudian diberi alkohol $70 \%$ yang berfungsi sebagai pengawet.

Adapun metode dan parameter yang diamati pada penelitian ini adalah, sebagai berikut:

\section{Identifikasi larva Ikan}

Identifikasi larva menggunakan buku identifikasi larva ikan [3], buku identifikasi karangan [4] dan buku Identifikasi karangan [5].

\section{Kelimpahan Larva Ikan}

Rumus kelimpahan larva yang digunakan adalah [6]:

$$
N=\frac{\sum n}{V t s a r}
$$

Keterangan :

$\mathrm{N}$ : Kelimpahan larva ikan (ind $/ \mathrm{m}^{3}$ )

$\mathrm{N}$ : Jumlah larva ikan (ind)

Vtsr : Volume air tersaring (m3)

Vtsr : Jarak dorongan $\mathrm{x}$ luas jaring.

Cara memperoleh nilai volume tersaring (m3) yaitu menggunakan rumus [7]:

$$
\mathrm{Vtsr}=\text { Ljaring } \mathrm{x} \mathrm{d}
$$

Keterangan :

$\begin{array}{ll}\text { Vtsr } & \text { : Volume air tersaring (m3) } \\ \text { Ljaring } & \text { : Luas jaring scoope net (m2) } \\ \text { d } & \text { : Jarak dorongan }\end{array}$

\section{Indeks Keanekaragaman}

Perhitungan Indeks keanekaragaman $(\mathrm{H}$ ') menurut [6] dengan formula sebagai berikut :

$$
H^{\prime}=\sum_{i=1}^{n} p i \ln p i
$$

Keterangan :

H' : ndeks Keanekaragaman

$\mathrm{Pi}:(\mathrm{ni} / \mathrm{N})$

$\mathrm{N}$ : nilai kepentingan total

ni : nilai kepentingan untuk tiap spesies

\section{Indeks keseragaman}

Perhitungan Indeks keseragaman berdasarkan persamaan [6] adalah sebagai berikut:

Keterangan:

$$
E=\frac{H^{\prime}}{H \max }
$$

$$
\begin{array}{ll}
\mathrm{H}^{\prime} & \text { : Indeks Shannon } \\
\mathrm{H} \max & : \ln \mathrm{S} \\
\mathrm{S} & : \text { jumlah spesies }
\end{array}
$$

Perhitungan Indeks Dominansi menggunakan Indeks Dominansi Simpson (Odum, 1993) [6] dengan rumus sebagai berikut :

Keterangan:

$$
D=\sum_{i=1}^{n}(n i / N)
$$

$\mathrm{C}$ : Indeks dominansi

$\mathrm{Ni}$ : Jumlah individu jenis ke-i

$\mathrm{N}$ : Jumlah total individu

\section{Pengukuran kondisi perairan}

Variabel kualitas air dilakukan bersamaan dengan sampling larva pada setiap wilayah penelitian, meliputi suhu menggunakan termometer air raksa, kecerahan dan kedalaman menggunakan secchi disk, kecepatan arus menggunakan bola arus (jeruk) dan stopwatch, salinitas menggunakan hand refraktometer dan $\mathrm{pH}$ menggunakan $\mathrm{pH}$ universal. 
Adapun analisis data yang akan digunakan yaitu data yang diperoleh akan dianalisis secara deskriptif yang digunakan untuk mendapatkan gambaran umum tentang sebaran data.

\section{HASIL DAN PEMBAHASAN}

\section{Komposisi dan Kelimpahan Larva Ikan}

Data komposisi dan kelimpahan larva ikan yang diperoleh dari hasil penelitian dapat dilihat pada Tabel 2. Berdasarkan Tabel 2, terlihat bahwa larva ikan yang tertangkap selama penelitian sebanyak 1.288 individu yang terdiri dari terdiri dari 7 famili yaitu Adrianichthyidae, Carangidae, Clupeidae, Engraulidae, Gerreidae, Gobiidae, dan Megalopidae. Tabel 2 memperlihatkan bahwa famili Gerreiidae paling banyak ditemukan di setiap lokasi sampling, diikuti oleh famili Gobiidae dan famili Adrianichthyidae. Sedangkan yang paling sedikit ditemukan selama penelitian yaitu dari famili carangidae, engraulidae, dan clupeidae.

Berdasarkan hasil penelitian komposisi dan kelimpahan larva ikan yang diperoleh pada setiap titik menunjukkan angka yang berbeda. Famili yang paling banyak ditemukan dan mendominasi di ekosistem mangrove Desa Bila-bila. Kecamatan Sajoanging yaitu Famili Gerreiidae dengan total kelimpahan yaitu 1004 ekor. Spesies ikan dari famili Gerreidae sangat menyukai perairan pantai dangkal termasuk ekosistem mangrove. Hal itu mengindikasikan bahwa spesies tersebut dapat bermigrasi secara bebas diantara habitat yang mangrove tersebut dikarenakan dukungan habitat baik dalam faktor lingkungan ataupun ketersediaan sumberdaya makanan [8]. Hal yang sama juga berdasarkan penelitian [9] bahwa famili Gerreidae memiliki jumlah tangkapan yang paling tinggi dan merupakan jenis yang mendominasi di satiap wilayah sampling, hal ini diduga karena daerah mangrove merupakan daerah asuhan yang cocok bagi famili Gerreidae.

Setelah famili Gerreidae, selanjutnya Larva ikan dengan kelimpahan tertinggi kedua yaitu dari famili Gobiidae. Famili Gobiidae juga hampir ditemukan disetiap wilayah penelitian dengan total kelimpahan 183 ekor. Famili Gobiidae merupakan kelompok ikan kelas Actinopterygii. Famili ikan ini biasanya hidup di perairan tawar hingga laut, ikan Gobiidae terdistribusi di seluruh dunia, yang meliputi habitat laut, estuari, dan air tawar. Hal ini dikarenakan kemampuan adaptasinya luas [10].

Tabel 2. komposisi dan kelimpahan larva ikan yang Tertangkap pada Lokasi Penelitian

\begin{tabular}{lccccccccccccc}
\multirow{2}{*}{ Famili } & \multicolumn{3}{c}{ Stasiun I } & \multicolumn{4}{c}{ Stasiun II } & \multicolumn{5}{c}{ Stasiun III } & $\Sigma$ \\
\cline { 2 - 15 } & A & B & C & $\sum$ & A & B & C & $\sum$ & A & B & C & $\sum$ & \\
\hline Adrianichthyidae & - & - & - & 0 & - & - & 3 & 3 & 23 & 15 & 31 & 69 & 72 \\
Carangidae & - & - & - & - & - & - & 2 & 2 & - & - & - & - & 2 \\
Clupeidae & - & - & - & 0 & 3 & 1 & 1 & 5 & 1 & - & - & 1 & 6 \\
Engraulidae & 2 & - & - & 2 & 1 & - & 1 & 2 & - & - & - & 0 & 4 \\
Gerreidae & 24 & 120 & 330 & 474 & 114 & 55 & 63 & 232 & 111 & 57 & 130 & 298 & 1004 \\
Gobiidae & 5 & - & 18 & 23 & 23 & 31 & 60 & 114 & 4 & 12 & 30 & 46 & 183 \\
Megalopidae & - & 3 & 1 & 4 & 4 & - & 1 & 5 & 3 & 3 & 2 & 8 & 17 \\
\hline JUMLAH & & & & $\mathbf{5 0 3}$ & & & & $\mathbf{3 6 3}$ & & & & $\mathbf{4 2 2}$ & $\mathbf{1 2 8 8}$ \\
\hline
\end{tabular}

Kelimpahan larva ikan tertinggi yang ketiga yaitu famili Adrianichthyidae dengan total kelimpahan di semua wilayah penelitian sebanyak 72 ekor. [11] famili Adrianichthyidae bersifat benthopelagic dan sering disebut sebagai ikan Padi dari habitat asli ikan tersebut, yaitu air tawar. Ikan ini mampu hidup juga di air payau yang sangat dipengaruhi pasang surut [12]. Famili Carangidae, Clupeidae, Engraulidae, dan 
Megalopidae juga ditemukan dilokasi penelitian tetapi memiliki kelimpahan yang rendah dan tidak ditemukan disetiap wilayah sampling. Hal ini diduga karena pola migrasi untuk mencari kondisi lingkungan yang sesuai dengan kebutuhan makanan untuk pertumbuhan setiap ikan berbeda-beda.

\section{Distribusi Sebaran Larva Ikan}

Data Distribusi sebaran larva ikan yang diperoleh selama penelitian dapat dilihat pada gambar 2 sebagai berikut :

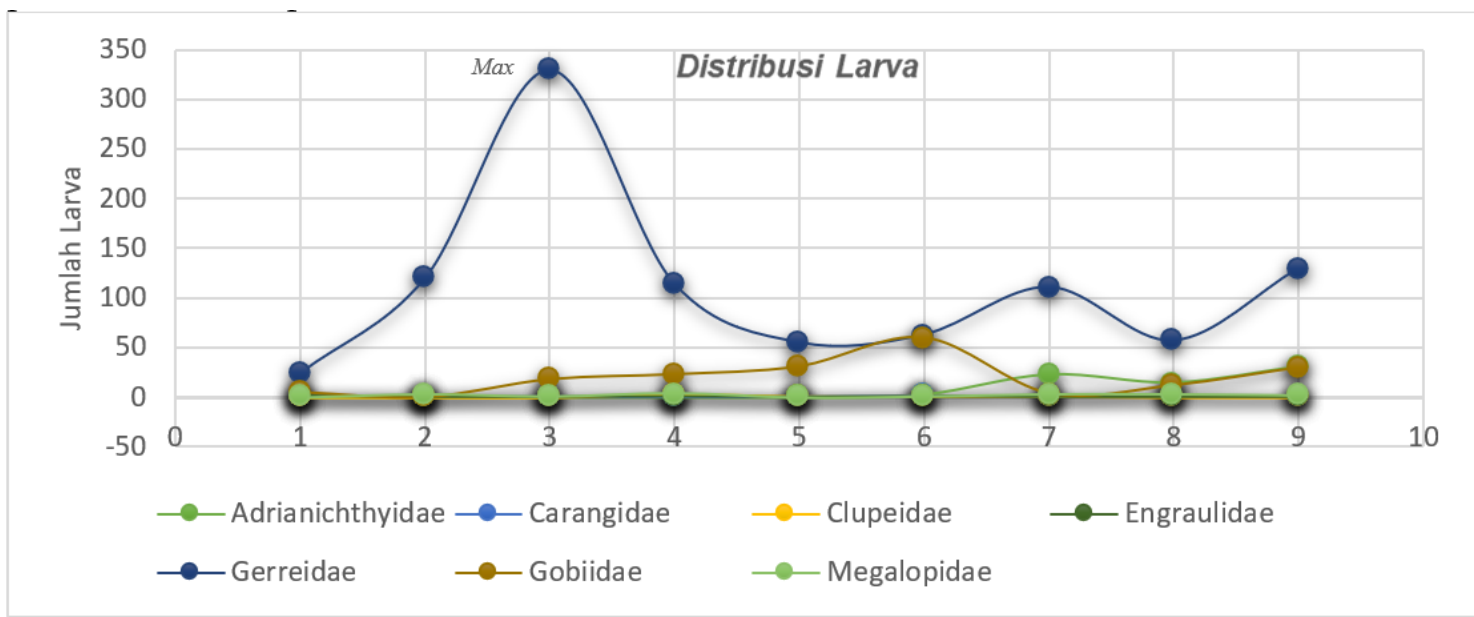

Gambar 2. Distribusi Sebaran Larva Ikan pada Wilayah I, Wilayah II dan Wilayah III

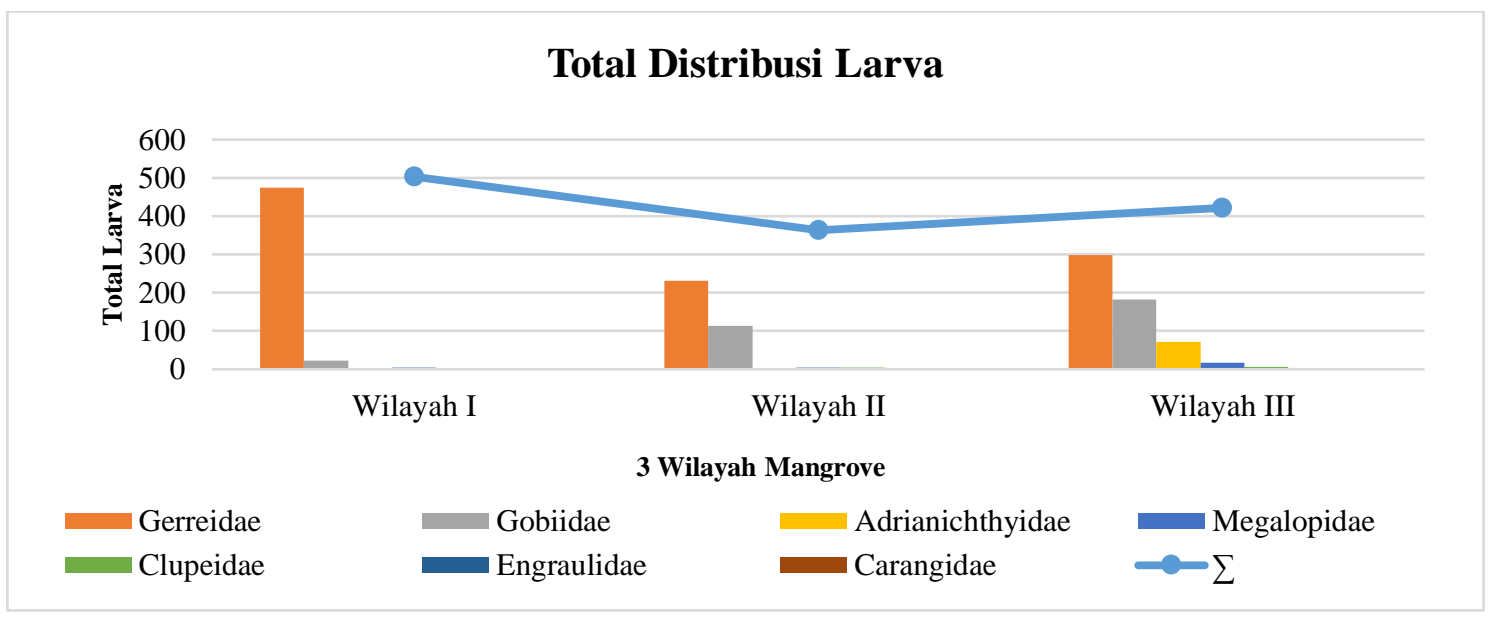

Gambar 3. Jumlah total Larva Ikan pada Wilayah I, Wilayah II dan Wilayah III

Berdasarkan gambar 1 diatas larva ikan yang tertangkap memiliki sebaran yang berbeda-beda pada lokasi penelitian. Famili Gerreidae dan Gobiidae memiliki sebaran yang cukup luas, dimana dapat ditemukan di seluruh wilayah. Sedangkan sebanyak 5 famili larva ikan hanya ditemukan lokasi tertentu saja. Histogram diatas menunjukkan bahwa pada wilayah II memiliki perolehan larva yang relatif lebih kecil dibandingkan dengan wilayah I dan Wilayah III, akan tetapi larva ikan yang tertangkap memiliki sebaran yang cukup berbeda-beda menurut lokasi penelitian. Famili Gerreidae dan
Gobiidae memiliki sebaran yang cukup luas, dimana dapat ditemukan di seluruh wilayah. Sedangkan sebanyak 5 famili larva ikan hanya ditemukan lokasi tertentu saja. Perbedaan nilai kelimpahan larva ikan pada setiap titik disebabkan oleh kondisi lingkungan setiap titik berbeda dan kemampuan adaptasi dari suatu biota dalam suatu ekosistem. Pola penyebaran biota dipengaruhi oleh tipe habitat yang meliputi parameter fisika kimia perairan serta makanan [13]. Kelimpahan rata-rata di tiga wilayah penelitian menunjukkan bahwa kelimpahan yang paling tinggi adalah di 
Stasiun I dan yang paling rendah adalah di Stasiun II.

Tabel 3. Rata-Rata Kelimpahan Larva Ikan (Ind/m3) pada Lokasi Penelitian

\begin{tabular}{cccc}
\hline \multicolumn{2}{c}{ Wilayah Penelitian } & Jumlah larva & Kelimpahan Larva Ikan Ind/m3 \\
\hline \multirow{3}{*}{ Stasiun I } & Minggu 1 & 298 & 25 \\
& Minggu 2 & 98 & 8 \\
& Minggu 3 & 107 & 9 \\
\hline \multirow{3}{*}{ Stasiun II } & Minggu 1 & 156 & 13 \\
& Minggu 2 & 142 & 5 \\
& Minggu 3 & 65 & 7 \\
\multirow{3}{*}{ Stasiun III } & Minggu 1 & 89 & 9 \\
& Minggu 2 & 110 & 19 \\
\hline
\end{tabular}

Keanekaragaman (H'), Indeks Keseragaman (e), dan Indeks Dominansi

Hasil analisis Indeks Keanekaragaman (H'), Indeks Keseragaman (e), dan Indeks
Dominansi (D) larva ikan berdasarkan penelitian yang telah dilakukan dapat dilihat pada Gambar 2, Gambar 3, dan Gambar 4, sebagai berikut :

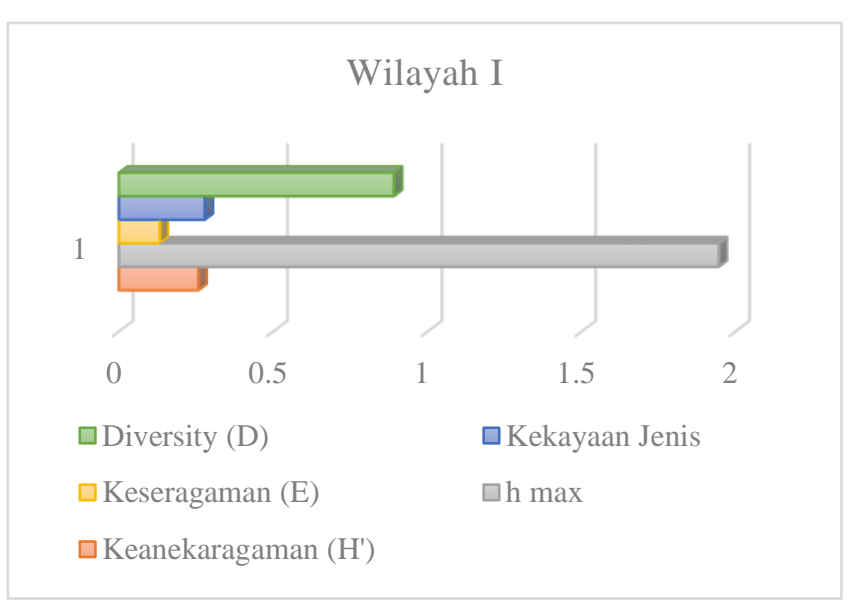

\begin{tabular}{|ll|}
\multicolumn{2}{c}{ Wilayah I } \\
\hline Keanekaragaman $\left(\mathrm{H}^{\prime}\right)$ & $\mathbf{0 , 2 5 7}$ \\
h max & $\mathbf{1 , 9 4 6}$ \\
Keseragaman (E) & $\mathbf{0 , 1 3 2}$ \\
Kekayaan Jenis & $\mathbf{0 , 2 7 8}$ \\
Dominansi (D) & $\mathbf{0 , 8 9 0}$ \\
\hline
\end{tabular}

Gambar 4. Indeks Keanekaragaman (H'), Indeks Keseragaman (e), dan Indeks Dominasi Larva Ikan wilayah I Penelitian. 


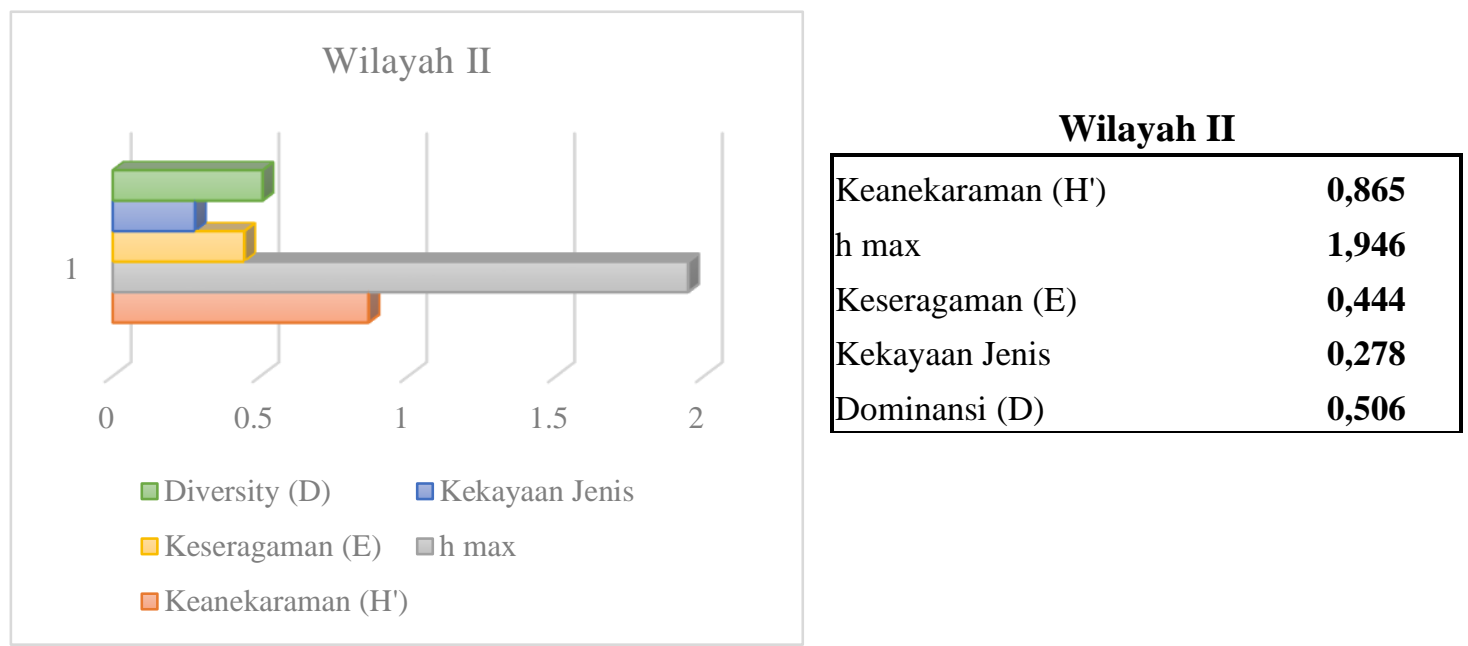

Gambar 5. Indeks Keanekaragaman (H’), Indeks Keseragaman (e), dan Indeks Dominasi Larva Ikan Wilayah II Penelitian.

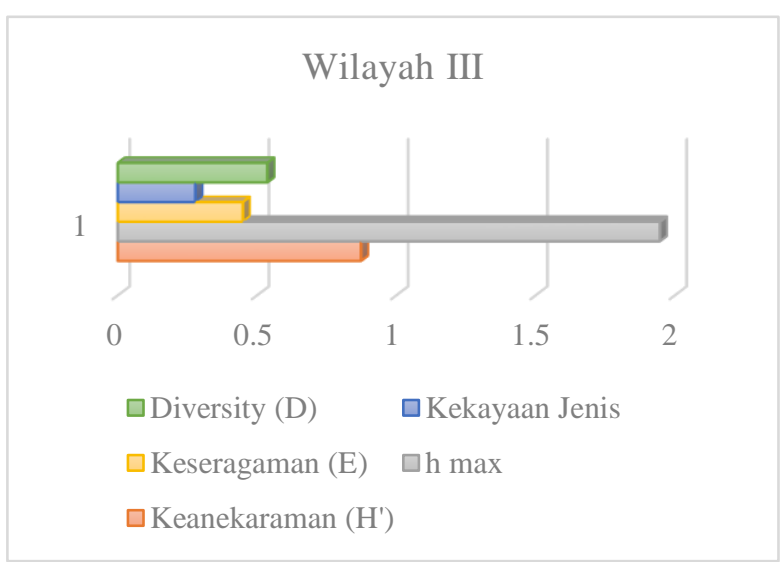

Wilayah III

\begin{tabular}{|ll|}
\hline Keanekaraman $\left(\mathrm{H}^{\prime}\right)$ & $\mathbf{0 , 8 7 3}$ \\
h max & $\mathbf{1 , 9 4 6}$ \\
Keseragaman (E) & $\mathbf{0 , 4 4 9}$ \\
Kekayaan Jenis & $\mathbf{0 , 2 7 8}$ \\
Dominansi (D) & $\mathbf{0 , 5 3 7}$ \\
\hline
\end{tabular}

Gambar 6. Indeks Keanekaragaman (H’), Indeks Keseragaman (e), dan Indeks Dominasi Larva Ikan Wilayah III Penelitian.

Hasil analisis Indeks Keanekaragaman $\left(H^{\prime}\right)$, Indeks Keseragaman (e), dan Indeks Dominansi (D) larva ikan menunjukkan nilai yang berfluktuatif. Pada setiap wilayah nilai indeks keanekaragaman berkisar antara 0,257-0,873 dari hasil analisis setiap wilayah menunjukkan keanekaragaman populasi yang rendah. Hal ini diduga terjadi karena masa pemijahan ikan berbeda-beda sehingga jumlah sebaran larva di dalam perairan sedikit. [11] mengemukakan bahwa suatu kondisi dimana mempunyai nilai Indeks Keseragaman kurang dari $1\left(\mathrm{H}^{\prime}<1\right)$ maka lokasi tersebut berada dalam kategori yang mempunyai tingkat keanekaragman rendah. Kelimpahan yang tidak merata pada semua famili ikan yang ditemukan, menjadikan nilai keanekaragaman tidak tinggi.

Indeks keseragaman (e) dianalisis untuk melihat seberapa besar kesamaan sebaran individu di dalam suatu komunitas atau populasi pada lokasi penelitian [7]. Hasil analisis menunjukkan bahwa pada setiap wilayah di lokasi penelitian memiliki nilai yang berbeda-beda. Nilai yang terendah berada pada wilayah I hal ini terjadi karena pada wilayah I terdapat satu jenis famili yang lebih mendominasi nilai keanekaragaman, selain itu selama melakukan sampling kelimpahan larva yang tidak merata pada setiap stasiun juga menyebabkan nilai indeks keanekaragaman menjadi rendah. Menurut [14], bahwa nilai 
indeks keseragaman pengamatan dibagi menjadi pada kriteria dengan kondisi labil dan stabil. Berdasarkan nilai indeks keanekaragaman yang didapatkan pada setiap wilayah maka ekosistem dikatakan labil karena nilai indek keseragaman wilayah penelitian berkisar 0,132-0,449.

Hasil analisis indeks dominansi antar wilayah pada lokasi penelitian diperoleh nilainya tergolong tinggi yaitu berkisar $0,506-0,890$, nilai ini menunjukkan bahwa pada lokasi penelitian terdapat jenis yang mendominasi pada suatu ekosistem. Menurut [15] menambahkan bila dalam suatu struktur komunitas biota yang diamati terdapat spesies yang mendominasi, maka hal ini menunjukkan bahwa kondisi struktur komunitas berada dalam keadaan labil atau sedang terjadi tekanan ekologis. Sedangkan yang terjadi saat penelitian berbanding terbalik, yaitu tidak ada yang mendominasi walaupun jika dilihat dari nilai indeks keseragaman, maka ekosistem tersebut masih tergolong labil. Menurut [16] Semakin kecil nilai e (Indeks Keseragaman), maka semakin kecil pula keseragaman populasi. Jadi apabila penyebaran jumlah individu setiap jenis tidak sama dan ada kecenderungan satu spesies mendominasi.

\section{Parameter Kualitas Perairan}

Kisaran nilai parameter Kualitas Perairan yang diperoleh selama penelitian disajikan pada tabel dibawah sebagai berikut:

Tabel 4. Hasil Pengukuran Nilai Parameter Kualitas Perairan Selama Penelitian

\begin{tabular}{llcccc}
\hline \multirow{2}{*}{ No } & \multirow{2}{*}{ Parameter } & \multirow{2}{*}{ Satuan } & \multicolumn{3}{c}{ Kisaran Nilai } \\
\cline { 5 - 6 } & & Suhu & I & II & III \\
\hline 2 & Kecerahan & ${ }^{\circ} \mathrm{C}$ & $27-34$ & $28-32$ & $27-33$ \\
3 & Kedalaman & $\mathrm{Cm}$ & $15,5-34,5$ & $17-30$ & $25-31,5$ \\
4 & Kecepatan Arus & $\mathrm{Cm}$ & $38-54$ & $38-58$ & $37-61$ \\
5 & Salinitas & m/detik & 0 & $0-0,05$ & $0-0,015$ \\
6 & $\mathrm{pH}$ & $\%_{0}$ & $27-31$ & $27-30$ & $27-30$ \\
\hline
\end{tabular}

Suhu suatu perairan sangat mempengauhi keberadaan ikan suhu air yang tidak sesuai dapat menyebabkan ikan tidak dapat tumbuh dan berkembang dengan baik, suhu air yang diperoleh selama penelitian yaitu berkisar antara $27-34^{\circ} \mathrm{C}$, kisaran tersebut masih tergolong layak untuk menunjang keberlangsungan hidup ikan. Suhu air yang cocok untuk pertumbuhan ikan di daerah tropis adalah berkisar antara $15^{0}-30^{0} \mathrm{C}$.

Selain suhu, $\mathrm{pH}$ air juga sangat berpengaruh terhadap kelangsungan hidup ikan. $\mathrm{pH}$ air dapat digunakan untuk menyatakan baik buruknya kondisi suatu perairan sebagai lingkungan hidup. Adapun $\mathrm{pH}$ air yang optimal yaitu berkisar antara 6 9. Nilai $\mathrm{pH}$ yang diperoleh selama penelitian berkisar 6-7 dan masih dalam kategori nilai $\mathrm{pH}$ yang baik dan bisa ditolerir oleh ikan. Kecerahan adalah ukuran sampai kedalaman berapa saja cahaya menembus kolom air, yang ditentukan secara visual dengan menggunakan secchi diks. Nilai kecerahan yang diperoleh pada wilayah penelitian yaitu berkisar 15,5-34,5 cm. Sedangkan untuk nilai kedalaman perairan yang diperoleh dari hasil penelitian yaitu berkisar 37-61 cm, dimana diperoleh data kedalaman wilayah I, wilayah II, dan Wilayah III berturut-turut adalah $38-54 \mathrm{~cm}, 38-58 \mathrm{~cm}$, dan $37-61 \mathrm{~cm}$. Untuk nilai kecepatan arus yang diperoleh di masing-masing lokasi penelitian yaitu berkisar 0-0,015 m/detik. Selain parameterparameter diatas, pada saat penelitian juga mengamati nilai salinitas di masing-masing wilayah tempat pengambilan sampel. Salinitas berpengaruh terhadap tingkah laku ikan ataupun distribusi ikan. Adapun kisaran nilai salinitas yang diperoleh yaitu 27-31 ppm. Kisaran tersebut masih tergolong layak dan mampu mendukung kehidupan organisme perairan. Menurut [17] nilai salinitas yang normal berkisar antara $30-40$ ppm. 


\section{KESIMPULAN}

Dari hasil penelitian dapat disimpulkan bahwa larva ikan yang ditemukan sebanyak 1288. Famili Gerreidae dan Gobiidae memiliki sebaran yang cukup luas, dimana dapat ditemukan di seluruh wilayah. Kelimpahan rata-rata di tiga wilayah penelitian menunjukkan bahwa kelimpahan yang paling tinggi adalah di Stasiun I dan yang paling rendah adalah di Stasiun II. Nilai indeks keanekaragaman berkisar antara 0,257-0,873, sedangkan indeks keseragamaan antara 0,132-0,449, dengan nilai tertinggi pada Stasiun III dengan umur mangrove 3 tahun. Nilai indeks Dominasi berkisar antara $0,506-0,890$, nilai tertinggi pada Stasiun I, dengan demikian dapat dilihat bahwa semakin tua umur mangrove semakin baik nilai struktur komunitasnya.

\section{UCAPAN TERIMA KASIH}

Penelitian ini didukung oleh Lembaga Penelitian dan Pengabdian Kepada Masyarakat Universitas Puangrimaggalatung, Kami berterima kasih kepada Pusat Penelitian Departemen Manajemen Sumber Daya Perairan Universitas Puangrimaggalatung dan Program Studi Perikanan Tangkap Universitas Sulawesi Barat yang telah bekerjasama dalam penelitian ini.

\section{DAFTAR PUSTAKA}

[1] Pramudji, "Hutan Mangrove Di Indonesia: Peranan Permasalahan Dan Pengelolaannya," Oseana, vol. XXV, no. 1, pp. 13-20, 2000.

[2] P. e. a. Claridge, "Seasonal changes in movements, abundance, size composition and diversity of the fish fauna of the Severn Estuary," Journal of the Marine Biological Association of the United Kingdom, vol. 66, no. 1, pp. 229-258, 2009.

[3] SEAFDEC, Larval Fish Identification Guide for the South China Sea and Gulf of Thailand., Bangkok: Southeast Asian Fisheries Development Centerin collaboration whit the UNEP/GEF South China Sea Project, 2013.

[4] M. Okiyama, An Atlas of the Early State Fishes in Japan, Japan: Tokai University Press, 1988.

[5] J. M. a. B. M. C.-E. Leis, The Larvae of Indo-Pacific Coastal Fishes an Identification Guide to Marine Fish Larvae, Netherlands.: Fauna Malesiana Foundation, 2000.

[6] E. P. Odum, Dasar-Dasar Ekologi, Yogyakarta: Gadjah Mada University Press, 1993.

[7] N. e. a. Riswandha, "Struktur Komunitas Larva Ikan pada Ekosistem Mangrove dengan Umur Vegetasi yang Berbeda di Desa Timbulsloko," Management of Aquatic Resources Journal (MAQUARES), vol. 4, no. 4, pp. 164-173, 2015.

[8] W. e. a. White, Market fishes of Indonesia, Australia: Australian Centre for International Agricultural Research (ACIAR)., 2013.

[9] F. e. a. Simanullang, "Distribution and Abundance of Fish Larvae in Mangrove Ecosystem in Pasar Banggi, District Rembang," Diponegoro Journal Of Maquares, vol. 5, no. 4, pp. 199-208., 2016.

[10] A. d. Khoncara, "Diet Composition and Feeding Strategy of Gobiid Fishes in Pabean Bay," Jurnal Ilmu Pertanian Indonesia, vol. 23, no. 2, pp. 137-147, 2018.

[11] S. Redjeki, "Komposisi dan Kelimpahan Ikan di Ekosistem Mangrove di Kedung malang," Indonesian Journal of Marine Sciences (IJMS), vol. 18, no. 1, pp. 5460, 2013.

[12] N. e. a. Subiyanto, "Pengaruh Pasang Surut terhadap Rekruitmen Larva Ikan di Pelawangan Timur Segara Anakan Cilacap," Jurnal Saintek Perikanan, vol. 5, no. 1, pp. 35-39, 2009. 
[13] R. K. E. A. Rinaldi, "Komposisi Larva Ikan Di Kawasan Koservasi Mangrove Dusun Senik, Desa Bedono, Kecamatan Sayung, Demak," Journal Of Maquares, vol. 6, no. 2, pp. 147155, 2017.

[14] R. Ambarita, "Keanekaragaman dan Distribusi Ikan di Hulu Sungai Asahan Porsea," Universitas Sumatera Utara, Medan, 2009.

[15] D. e. al, "Struktur Komunitas Larva Ikan Pada Ekosistem Mangrove Dengan Umur Vegetasi Yang Berbeda Di Desa Timbulsloko," Diponegoro Journal Of Maquares, vol. 4, no. 4, p. 164:173, 2009.

[16] S. e. a. Redjeki, "Struktur Komunitas Ikan pada Ekosistem Mangrove di Desa Bedono Sayung, Demak," Buletin Oseanografi Marina, vol. 2, pp. 78-86, 2013.

[17] R. Syamsuddin, Pengelolaan Kualitas Air:Teori dan Aplikasi Di Sektor Perikanan, Makassar: Pijar Press, 2014. 